SAVINGS CONSTRAINTS AND MICROENTERPRISE DEVELOPMENT: EVIDENCE FROM A FIELD EXPERIMENT IN KENYA

Pascaline Dupas

Jonathan Robinson

WORKING PAPER 14693 
NBER WORKING PAPER SERIES

\title{
SAVINGS CONSTRAINTS AND MICROENTERPRISE DEVELOPMENT: EVIDENCE FROM A FIELD EXPERIMENT IN KENYA
}

\author{
Pascaline Dupas \\ Jonathan Robinson \\ Working Paper 14693 \\ http://www.nber.org/papers/w14693
NATIONAL BUREAU OF ECONOMIC RESEARCH
1050 Massachusetts Avenue
Cambridge, MA 02138
January 2009

For helpful discussions and suggestions, we are grateful to Orazio Attanasio, Jean-Marie Baland, Leo Feler, Fred Finan, Sarah Green, Seema Jayachandran, Dean Karlan, Ethan Ligon, Craig McIntosh, David McKenzie, John Strauss, Dean Yang, Chris Woodruff, two anonymous referees, and participants at numerous seminars and conferences. We thank Jack Adika and Anthony Oure for their dedication and care in supervising the data collection, and Nathaniel Wamkoya for outstanding data entry. We thank Eva Kaplan, Katherine Conn, Sefira Fialkoff, and Willa Friedman for excellent field research assistance, and thank Innovations for Poverty Action for administrative support. We are grateful to Aleke Dondo of the K-Rep Development Agency for hosting this project in Kenya, and to Gerald Abele for his help in the early stages of the project. Dupas gratefully acknowledges the support of a Rockefeller Center faculty research grant from Dartmouth College and Robinson gratefully acknowledges the support of an NSF dissertation improvement grant (SES-551273), a dissertation grant from the Federal Reserve Bank of Boston, and support from the Princeton University Industrial Relations Section. We also gratefully acknowledge the support of the World Bank. All errors are our own. The views expressed herein are those of the author(s) and do not necessarily reflect the views of the National Bureau of Economic Research.

NBER working papers are circulated for discussion and comment purposes. They have not been peerreviewed or been subject to the review by the NBER Board of Directors that accompanies official NBER publications.

(C) 2009 by Pascaline Dupas and Jonathan Robinson. All rights reserved. Short sections of text, not to exceed two paragraphs, may be quoted without explicit permission provided that full credit, including (C) notice, is given to the source. 
Savings Constraints and Microenterprise Development: Evidence from a Field Experiment in Kenya

Pascaline Dupas and Jonathan Robinson

NBER Working Paper No. 14693

January 2009, Revised March 2012

JEL No. G21,L26,O12

\begin{abstract}
Does limited access to formal savings services impede business growth in poor countries? To shed light on this question, we randomized access to non-interest-bearing bank accounts among two types of self-employed individuals in rural Kenya: market vendors (who are mostly women) and men working as bicycle-taxi drivers. Despite large withdrawal fees, a substantial share of market women used the accounts, were able to save more, and increased their productive investment and private expenditures. We see no impact for bicycle-taxi drivers. These results imply significant barriers to savings and investment for market women in our study context. Further work is needed to understand what those barriers are, and to test whether the results generalize to other types of businesses or individuals.
\end{abstract}

Pascaline Dupas

Department of Economics

Stanford University

579 Serra Mall

Stanford, CA 94305-6072

and NBER

pdupas@stanford.edu

Jonathan Robinson

Department of Economics

University of California, Santa Cruz

457 Engineering 2

Santa Cruz, CA 95064

jmrtwo@ucsc.edu 


\section{Introduction}

Hundreds of millions of people in developing countries earn their living through small-scale business (World Bank, 2004; de Soto, 1989). Many of these entrepreneurs do not have access to even the most basic of financial services, such as a simple bank account in which they can save money! 1 Given that many entrepreneurs need to save up daily profits for lumpy investments or set aside some money to use for unexpected shocks, is it possible that not having a place to save securely impedes business success?

In this paper, we test this directly by expanding access to bank accounts for a randomly selected sample of small informal business owners in one town of rural Western Kenya. The sample is composed primarily of market vendors (the great majority of whom are women) and bicycle-taxi drivers (all of whom are men), and includes 250 individuals in total. We use two main data sources to measure impacts: administrative data from the bank on account usage, and a rich dataset constructed from daily logbooks which were kept by respondents. The logbooks include detailed information on many outcomes, including formal and informal savings, business investment, and expenditures.2

There are three main findings. First, market women in the treatment group used the bank accounts quite actively, and increased their total savings on average. Treated bicycle-taxi drivers (all of whom were men) used the accounts much less and did not increase their total savings. The high account usage rate among market women is especially noteworthy because the account did not pay out any interest and included substantial withdrawal fees, so that the de facto interest rate on deposits was negative (even before accounting for inflation) $!^{3}$ Clearly, if female vendors did not have trouble saving on their own, they should not have paid the bank for the right to save. That they voluntarily did so suggests that they face negative private returns on the money they save informally.

Second, market women in the treatment group substantially increased their investment in their business relative to the control group. Our most conservative estimate of the effect is equivalent to a 38-56\% increase in average daily investment for market women after 4-6 months. While this point estimate is very large, the standard errors are also quite large and the confidence interval includes both reasonable and less reasonable effect sizes. Our focus is thus on the fact that we see a substantial positive impact, rather than on its exact

\footnotetext{
${ }^{1}$ Though there is little evidence for entrepreneurs specifically, several studies show extremely low levels of financial access for the broader population in developing countries (Chaia et al., 2009; Kendall et al., 2010). With regards to Africa more specifically, Aggarwal et al. (2011) use the Gallup World Poll to show that only $15 \%$ of people in Sub-Saharan Africa have a bank account.

${ }^{2}$ The logbooks are similar to the financial diaries used in Collins et al. (2009).

${ }^{3}$ Inflation in Kenya was between 10 and $14 \%$ between 2006 and 2009, the time period of this study (IMF, 2010).
} 
magnitude. $4^{4}$

Third, market women in the treatment group had significantly higher expenditures than market women in the control group. After four to six months, daily private expenditures were about $37 \%$ higher for market women in the treatment group.

This study is the first randomized field experiment estimating the effect of expanding access to basic savings accounts. There have, however, been a number of recent randomized controlled trials which look at the effects of increased access to credit. Our findings contrast with those studies in two ways. First, studies exploiting the randomized expansion of microcredit have observed relatively low take-up: $27 \%$ of households in urban India (Banerjee et al., 2009) and 16\% of households in Morocco (Crépon et al, 2011) took out a loan when barriers to access were lowered. In rural Kenya, less than $3 \%$ of individuals initiate a loan application even after receiving assistance with the collateral requirement (Dupas et al., 2012). In contrast, $87 \%$ of people took up the savings account we offered, and $41 \%$ made at least two transactions within the first six months of getting the offer $5^{5}$

Second, while we find evidence that savings access helps increase business investment, evidence on the impact of credit on microentrepreneurs so far has been quite mixed. Karlan and Zinman (2010a, b) exploit randomized access to credit in an urban area in the Philippines, and see no effect of microcredit access on business investment; rather, they find some evidence that the size and scope of businesses shrink when their owner gets a loan..$^{6}$ In contrast, Banerjee et al. (2009) find positive (though still quite small in absolute magnitude) impacts on business creation and purchase of business durables by business owners. Finally, Kaboski and Townsend (2011) evaluate a natural experiment which increased credit access in rural Thailand. They find large consumption impacts, but no change in overall investment. The only randomized controlled trial to find large, positive impacts thus far is Attanasio et al. (2012) in Mongolia.

There have also been a few non-experimental studies estimating the impact of providing comprehensive financial services (i.e., both savings and credit) on income (Burgess and Pande, 2005, in India; Bruhn and Love, 2009, and Aportela, 1999, in Mexico; and Kaboski and Townsend, 2005, in Thailand). Our paper adds to this literature by providing exper-

\footnotetext{
${ }^{4}$ Note however that qualitative debriefing interviews with women who saw large increases in business size supported the quantitative estimates.

${ }^{5}$ This higher demand for saving than credit supports the results of earlier observational studies, such as Johnston and Morduch (2008), who show that 90\% of Bank Rakyat Indonesia clients save but do not borrow; or Bauer, Chytilová, and Morduch (2010), who argue that some women in India take up microcredit schemes as a way of forcing themselves to save through required installment payments (rather than to access credit for use in a business).

${ }^{6}$ The authors explain this negative impact as follows: increased access to credit reduced the need for favortrading within family or community networks and thereby enabled business owners to shed unproductive workers.
} 
imental evidence that providing basic saving services alone might be an important tool in poverty alleviation.

Our findings raise a number of issues that remain to be explored. First, what are the key savings barriers that bank accounts help overcome? Do people have difficulty saving because they have present-biased preferences and over-consume cash on hand, as has been shown to be the case for at least $10 \%$ of women in the Philippines (Ashraf, Karlan, and Yin, 2006)? Or do they have difficulty protecting their savings from demands from others (Platteau, 2000)?

Second, and relatedly, while the private return on savings at home appears to be negative, the social return could be zero: every dollar given out to a relative or social contact who asks for it is ultimately spent. Savings accounts only improve welfare if they make it more likely that money is spent where it has the highest return (for example, if it allows a relatively high-return entrepreneur to increase investment) or if it reduces money spent on consumption that people later regret (temptation goods, for example). This implies that the welfare implications of increasing access to formal saving services to a subset of the population are ultimately unclear - while market women in the treatment group were clearly better off, the impact on other members of their social network is uncertain. They could benefit in the long run from the higher resources generated by women through their expanded businesses, but they may suffer in the short run from receiving lower transfers.

Third, how generalizable are these results? Within our own sample, we find important heterogeneity by occupation, with no effect for bicycle taxi drivers and large effects for female market vendors (we lack precision to estimate the importance and impact of saving constraints for male vendors). How would other segments of the population (for example, farmers) be affected by access to savings services? We leave more thorough investigation of these issues to future work.

The remainder of the paper is as follows. We first describe the experiment and the data in Section 2, before presenting the main results in Section 3. Section 4 presents the panel data evidence on risk-coping. Section 5 discusses potential mechanisms and open questions, and Section 6 concludes.

\section{Experimental Design and Data Collection}

\subsection{Study Location and Study Population}

The study took place in and around Bumala Town in Busia district, Kenya. Bumala Town is a rural market center located along the main highway connecting Nairobi, Kenya, to 
Kampala, Uganda, and it has a population of around 3,500, making it the fifth largest town in Busia district and the 189th largest town in Kenya.7

As this project was focused on non-farm microenterprises rather than on a more general population, our sample consisted solely of daily income earners. We decided to focus in particular on vendors and on bicycle taxi drivers, which are two popular types of own enterprises in Bumala Town. Though there are many other types of businesses in the area, we focused on these two types because the production function is similar across businesses within each type.

The scale of operations for individuals in our sample is quite small. For those involved in vending, the mean number of items traded is just below 2, and the median is 1 (the majority of vendors sell just one item, such as charcoal or a food item like dried fish or maize). Mean daily investment is just US $\$ 6$ per day. For bicycle-taxi drivers, mean investment is limited to bicycle repairs, which amount to only US $\$ 1$ per day on average. Most of the individuals in our sample own a small plot of land and are involved in subsistence farming in addition to their business. The main staple crop cultivated is maize.

\subsection{Background on formal and informal savings in Western Kenya}

Most self-employed individuals in rural Kenya do not have a formal bank account. At the onset of this study, only $2.2 \%$ of individuals we surveyed had a savings account with a commercial bank. The main reasons given for not having an account were that formal banks typically have high opening fees and have minimum balance requirements (often as high as $500 \mathrm{Ksh}$, or around US \$7). Savings accounts are also offered by savings cooperatives, but the cooperatives are usually urban and employment based, and therefore rarely available for rural self-employed individuals.

Instead, individuals typically save in the form of animals or durable goods, in cash at their homes, or through Rotating Savings and Credit Associations (ROSCAs), which are commonly referred to as merry-go-rounds 8 Most ROSCAs have periodic meetings, at which members make contributions to the shared saving pool, called the "pot". The pot money is given to one member every period, in rotation until everyone has received the pot. ROSCA participation is high in Kenya, especially among women, and many people participate in multiple ROSCAs (Gugerty, 2007).

In our sample, $87 \%$ of respondents report that "it is hard to save money at home", and ROSCA participation) is widespread, especially among women (Table 1).

\footnotetext{
${ }^{7}$ See http://kenya.usaid.gov/sites/default/files/profiles/Busia_Dec2011\%2020.pdf

${ }^{8} \mathrm{It}$ is very common for people around the developing world to use these types of mechanisms as primary savings mechanisms (Rutherford, 2000).
} 


\subsection{The Village Bank}

We worked in collaboration with a village bank (also called a Financial Services Association, or FSA) in Bumala Town. The Bumala FSA is a community-owned and operated entity that receives support (in the form of initial physical assets and ongoing audit and training services) from the Kenya Rural Enterprise Development Agency, an affiliate of the Kenyan microfinance organization KREP. The FSA is the only financial institution present in the study area. Commercial bank branches are available in the next town (Busia), located about 25 kilometers away.

At the time of the study, opening an account at the village bank cost 450 Ksh (US \$6.40). The village bank did not pay any interest on the savings account. However, the bank charged a withdrawal fee (of US $\$ 0.50$ for withdrawals less than US $\$ 8, \$ 0.80$ for withdrawals between $\$ 8$ and $\$ 15$, and $\$ 1.50$ for larger withdrawals), thus generating a de facto negative interest rate on savings. The bank was open from Monday to Friday from 9am to 3pm, and did not provide ATM cards or any opportunity to deposit or withdraw money at any time outside these working hours, making bank savings somewhat illiquid - savings could not be accessed for emergencies which occurred on the weekend or after $3 \mathrm{pm}$.

The village bank opened in Bumala Town in October 2004. By the time this study began in early 2006, only $0.5 \%$ of the daily income earners that we surveyed around Bumala Town had opened an account at the village bank. The main reasons given by respondents for why they did not already have an account were inability to pay the account opening fee, and lack of information about the village bank and its services $!^{9}$

Note that access to credit is also extremely limited in the study area. At the time of the study, there was no microcredit agency lending to people in our sample. Only those with a bank account at the Village Bank could potentially be eligible for a loan, but the eligibility criteria were extremely stringent. Consequently, very few people in our study received credit during the sample period.

\subsection{Sampling}

The sampling was done in three waves, in 2006, 2007 and 2008, respectively. Given that we had only a limited budget for data collection, in each wave we sampled people up to the point that we had enough staff to oversee the daily logbook data collection exercise (the logbooks, as we discuss below, were costly to administer because they required a high

\footnotetext{
${ }^{9}$ Cole, Sampson and Zia (2011) combine experimental and survey evidence from India and Indonesia to argue that the demand for bank savings accounts is not constrained by lack of financial literacy, but rather by high prices.
} 
ratio of well-trained enumerators to respondents). To draw the sample, enumerators were assigned specific areas in and around Bumala town, and asked to identify market vendors and bicycle-taxi drivers operating there. They administered a background survey to these individuals upon identifying them. ${ }^{10}$ Those that already had a savings account (either at the village bank itself or some other formal bank) were excluded from the sample. This criterion excluded very few individuals: as mentioned above, only $2.2 \%$ of individuals had accounts in a commercial bank and $0.5 \%$ had accounts in the FSA. After excluding these individuals, our final sample frame consisted of 392 individuals: 262 female vendors, 92 male bicycle taxi drivers, and 34 male vendors (see Appendix Table A1). This represents only a small share of the total population in Bumala Town, and a small share of vendors and bicycle taxi drivers.11

\subsection{Experimental Design and Timeline}

Individuals in the sample frame were randomly divided into treatment and control groups, stratified by gender and occupation (gender and occupation are very highly correlated in the sample, since all women in the sample are market vendors and $89 \%$ of market vendors in the sample are female). Those sampled for treatment were offered the option to open an account at the village bank at no cost to themselves - we paid the account opening fee and provided each individual with the minimum balance of $100 \mathrm{Ksh}$ (US \$1.43), which they were not allowed to withdraw. Individuals still had to pay the withdrawal fees, however. Those individuals that were sampled for the control group did not receive any assistance in opening a savings account (though they were not barred from opening one on their own) 12

The timing was as follows. In Wave 1, the background survey was administered in February and March 2006, and accounts were opened for consenting individuals in the treatment group in May 2006. In Wave 2, the background survey was administered in April and May 2007 and accounts were opened in June 2007. In Wave 3, the background survey was administered in July and August 2008 and accounts were opened in June $2009{ }^{13}$

\footnotetext{
${ }^{10}$ We did not keep track of the number of individuals that were approached but refused to be surveyed, but reports from enumerators suggest that refusals were very rare at the enrollment stage.

${ }^{11}$ In a census of ROSCA participants around Bumala Town that we conducted for a separate study (Dupas and Robinson, 2012), we identified over 800 female vendors. Records kept by Bumala's Boda association indicate that over 300 bodas were registered in 2007.

${ }^{12}$ Within the study period, three individuals in the control group opened accounts in the village bank on their own.

${ }^{13}$ After the data had been collected, control individuals in each wave were given the option to open a savings account free of charge as compensation for participating in the study, but this was not anticipated.
} 


\subsection{Data}

We use four sources of data. First, our background survey includes information on the baseline characteristics of participants, such as marital status, household composition, assets, and health. Second, we have administrative data from the village bank on every deposit and withdrawal made in all of the treatment accounts.14

Third, we elicited time and risk preferences from respondents, as well as cognitive ability measures. ${ }^{15}$ The time preference questions asked respondents to decide between 40 Ksh now (US \$0.57) and a larger amount a month later. To measure time consistency, we also asked respondents to choose between $40 \mathrm{Ksh}$ in 1 month and a larger amount in 2 months. The risk preference questions were similar to Charness and Genicot (2009) and asked respondents how much of $100 \mathrm{Ksh}(\$ 1.43)$ they would like to invest in an asset that paid off four times the amount invested with probability 0.5 and that paid off 0 with probability $0.5{ }^{16}$ To measure cognitive ability, we asked respondents to complete a "Raven's Matrix" in which they had to recognize patterns in a series of images.

Fourth, and most importantly, we collected detailed data on respondents through daily, self-reported logbooks. These logbooks included detailed income, expenditure, and business modules, as well as information on labor supply and on all transfers given and received (including between spouses).

Because the logbooks were long and complicated to keep, trained enumerators met with the respondents twice per week to verify that the logbooks were being filled correctly. One significant challenge was that many respondents could neither read nor write $(33 \%$ of women and $9 \%$ of men who agreed to keep the logbooks could not read nor write Swahili). To keep these individuals in the sample, enumerators visited illiterate respondents every day to help them fill the logbook.

To keep data as comparable as possible, respondents kept logbooks during the same time period in each wave, from mid-September to mid-December. Logbooks were kept in 2006 for Wave 1, 2007 for Wave 2, and 2009 for Wave 3. To encourage participation, the logbooks were collected every four weeks, and respondents were paid $50 \mathrm{Ksh}(\$ 0.71)$ for each week the logbook was properly filled (as determined by the enumerator) 17 Though respondents were

\footnotetext{
${ }^{14}$ We obtained consent from respondents to collect these records from the bank.

${ }^{15}$ This type of data was collected from all study participants in 2008. This means that, for respondents in Waves 1 and 2, the data was collected after the treatment had been implemented, whereas for respondents in Wave 3 it was collected at baseline. Since the treatment (getting a bank account) might have affected risk and time preferences among subjects, we do not make any strong conclusions regarding the heterogeneity of the treatment effect by these measures, but instead consider them as purely suggestive.

${ }^{16}$ To encourage truth-telling, one of the risk and time preference questions was randomly selected for actual payment.

${ }^{17}$ This figure is equivalent to about one-third of daily total expenditures for respondents in this sample.
} 
asked to fill the logbooks for up to 3 months, some were only willing to keep the logbooks for a shorter period, and so we do not have 3 full months' worth of data for all respondents.

The logbook data makes up the bulk of the analysis. For each respondent, we compute the average daily business and household expenditures across all the days that the respondent filled the logbook, and then compare these averages between the treatment and control groups.

The logbooks included a module designed to estimate respondents' investment, hours worked and sales. From this, we planned to back out profits. However, the imputed profits are ultimately unusable. This is because the quality of the data on revenues from the business (mostly retail sales) is very poor. Many respondents did not keep good records of their sales during the day, in part because they did not have time to record each small retail transaction that they had. In contrast, the data on business investments (mostly wholesale purchases) is relatively reliable, albeit somewhat noisy. As a result, total business revenues are systematically smaller than total investment, and so total profits are on average very negative in the sample. What is problematic for us is that under-reporting of revenues appears to increase with the size of the business (the more sales, the higher the share of unrecorded sales). Given this, we estimate impacts on investment and revenues separately. ${ }^{18}$

\subsection{Attrition}

There were two main sources of attrition. The first is that some respondents could not be found and asked to keep the logbooks (because they had moved or could not otherwise be traced). The second is that, as might be imagined from the length of the logbooks and the relatively small compensation given to participants, some people refused to fill the logbooks. Of those who could be traced and offered logbooks, $17 \%$ refused to fill them $(7 \%$ of women and $21 \%$ of men).

We document attrition in Appendix Table A1. Among female vendors, we had more difficulty tracing those in the treatment group, but acceptance to fill the logbook was not differential (conditional on being traced). But bodas, who were much more likely to attrit than market women, attrited differentially: bodas in the treatment group were both more likely to be found, and more likely to accept the logbooks if found, than those in the control group. Male vendors were more likely to attrit from the treatment group. As we show in the next section, the post-attrition treatment and control groups that make it into the final

\footnotetext{
${ }^{18}$ While it is unfortunate that we do not have reliable profit measures, we note that it is notoriously difficult to measure profits for such small-scale entrepreneurs, especially since most do not keep records (Liedholm, 1991; Daniels, 2001). We did not ask respondents to report their profit directly, which, in hindsight, appears to have been a mistake: de Mel et al. (2009a) show that asking respondents to report profits is more reliable than trying to back out profits from business transaction details.
} 
analysis do not differ along most observable characteristics, but the differential attrition patterns make it impossible to rule out unobservable differences between treatment and control groups among bodas, who represent $80 \%$ of the men in our sample. While this attrition limits confidence in the results, it is unlikely that bodas could have benefited from the accounts since the amounts they deposited on their accounts were very modest(according to the bank administrative records, which do not suffer from an attrition problem. See Figure 2.)

\subsection{Final Sample Characteristics and Balance Check}

Table 1 presents baseline characteristics of men and women that filled the logbooks by treatment status, and the p-values of tests that the differences between treatment and control are equal to zero 19 We have 250 logbooks in total, 170 of which were filled by market women and 80 of which were filled by men (55 bicycle-taxi drivers and 25 market men). ${ }^{20}$ The background variables are mostly self-explanatory, but we describe briefly the time preference measures. We define as "somewhat patient" any respondent who preferred $55 \mathrm{Ksh}$, or $\$ 0.79$, (or less) in 1 month to $40 \mathrm{Ksh}(\$ 0.57)$ today. For measures of time consistency, we assign people to one of four categories: (1) "present-biased" respondents who are less patient in the present than in the future; (2) respondents who exhibit maximum possible discount rates in both the present and future (these individuals preferred $40 \mathrm{Ksh}$ to $500 \mathrm{Ksh}(\$ 7.14)$ in 1 month, and $40 \mathrm{Ksh}$ in 1 month to $500 \mathrm{Ksh}$ in 2 months); (3) respondents who are more patient in the present than in the future; and (4) "time-consistent" individuals who have the same discount rate in the present and the future.

As can be seen in Table 1, around $21 \%$ of women and $5 \%$ of men were actually more patient in the present than in the future. Though this seems counter-intuitive, previous studies have found similar results: about $10 \%$ of respondents in Bauer, Chytilová, and Morduch (2010) and 15\% of respondents in Ashraf, Karlan and Yin (2006) had preferences of this type in studies in India and the Philippines, respectively. ${ }^{21}$

For both market women and men, the treatment and control groups are balanced along

\footnotetext{
${ }^{19}$ Standard errors of the differences are clustered at the individual level to account for the fact that Wave 1 control individuals appear twice (as controls in 2006 and treatment in 2007).

${ }^{20} \mathrm{We}$ have fewer observations for the time preference, risk preference, and cognitive ability module. In total, we have 220 observations for these variables.

${ }^{21}$ At the same time, many respondents in our Kenya sample were extremely impatient compared to the samples in those two studies. This does not appear to be solely because people did not understand the questions they were asked, or because they did not trust that payouts in the future would be delivered (if chosen): in general, respondents showed similar levels of impatience in the future as in the present, even though all payouts for the future questions would be delivered later (in 1 or 2 months, depending on the answer to the question).
} 
most background characteristics. For women, the p-value of the difference between treatment and control is above 0.10 for all 24 baseline characteristics presented in Table 1 . These figures suggest that attrition during the logbook exercise was not differential along observable characteristics for market women, and performing the analysis on the restricted sample for which we have data will not bias our estimates of the treatment effect.22

There is more reason for concern among men. Four background characteristics have statistically significant differences between treatment and control men (education, ROSCA contributions, extreme impatience in both present and future, and an indicator for Wave 3), and we know from Table A1 that there was differential attrition among bodas (which explains the imbalance between groups in terms of occupation, see row 4). This differential attrition means that there may well be unobservable differences between treatment and control bodas, and thus our estimates of the treatment effects on bodas may suffer from selection bias. On the other hand, our estimates of the treatment on male vendors suffer from a tiny sample size.

All in all, the sample of men for whom we have data has much lower validity (both internally and externally) than our sample of market women. To deal with this issue, we perform all our analyses with interaction terms between experimental treatment and type, and we focus our attention on the results for market women.

Finally, a natural question is how representative these individuals are of the general population in the area. Appendix Table A2 explores this, using data collected from a representative sample of unbanked households in a nearby area for Dupas et al. (2012), as well as representative samples of unbanked households in rural Uganda and rural Malawi collected for ongoing projects. In column 1, we reproduce the summary statistics shown in Table 1 for our study sample, combining women and men. In columns 2-4, we show the summary statistics for the three other samples. Our respondents are somewhat younger, more likely to be literate, more likely to participate in ROSCAs, and somewhat poorer in terms of durable assets. They are indistinguishable in terms of risk preferences and access to formal credit. Overall, while we acknowledge that our sample is selected, our respondents seem to be relatively comparable to the average rural unbanked adult in East Africa.

\footnotetext{
${ }^{22}$ One potentially important difference is income (which is higher in treatment than control), particularly since several of our key outcomes are proxies for post-treatment income. Note, however, that the standard deviations of the baseline means are extremely large, and the difference is nowhere close to significant. We do not control for this variable in most specifications because the variable is missing for several respondents. Including it as a control does not change the results, though we lose power due to the reduced sample size. Results with alternative control choices are available upon request.
} 


\section{Results}

\subsection{Take-up}

A total of 156 respondents had the opportunity to open a savings account through this program. Twenty-one of them (13\%) refused to open the account, while another $40 \%$ opened an account but never made a single deposit. Figure 1 shows the histogram of the number of transactions made by treatment individuals at the village bank within the first 6 months of being offered the account. As can be seen, many individuals never used the account or only used it rarely, though others used it regularly.

Figure 2 plots the cumulative distribution functions of the total amount deposited in the account in the first 6 months, separately by gender. For readability, Panel A plots the CDFs below the 75th percentile while Panel B plots the CDFs above the 75th percentile. The distribution for men is clearly dominated by the distribution for women, especially at the upper end of the distribution. While median deposits are actually 0 Ksh for both genders, the $75 \mathrm{th}$ and $90 \mathrm{th}$ percentiles of total deposits are $350 \mathrm{Ksh}(\$ 5.00)$ and 1,200 Ksh (\$17.14) for men, but $725 \mathrm{Ksh}(\$ 10.35)$ and 5,650 Ksh (\$80.71) for women.23 Mean deposits are more than twice as high for women: they are 1,290 Ksh (\$18.42) for men and 2,840 Ksh $(\$ 40.57)$ for women.

\subsection{Impact: Estimation Strategy}

This section estimates the effect of the savings account on average daily savings, business investment, and expenditures. For each outcome, there are two level effects of interest: the intent-to-treat effect (ITT), the average effect of being assigned to the treatment group; and the average effect for those that actively used the account (the Treatment on the Treated or ToT effect).

We first estimate the overall average effect of being assigned to the treatment group (the intent-to-treat effect) on a given outcome $Y$ using the following specification:

$$
Y_{i t}=\alpha_{1}+\beta_{1} T_{i t}+X_{i}^{\prime} \phi_{1}+\sum_{k=07,09}\left(\theta_{1} \text { year }_{i t}^{k}+\vartheta_{1} M_{i} \times \text { year }_{i t}^{k}+\lambda_{1} M_{i} \times B_{i} \times \text { year }_{i t}^{k}\right)+\varepsilon_{1 i t}
$$

where $T_{i t}$ is an indicator which is equal to 1 if individual $i$ had been assigned to the treatment group (sampled for an account) in year $t, X_{i}$ is a vector of baseline characteristics (including gender and occupation), and year $r_{i t}^{k}$ is a dummy equal to 1 if the logbook data was collected in year $k$ (2006, 2007 or 2009 in our data). Since the randomization was done after stratifying

\footnotetext{
${ }^{23}$ Formally, a Kolmogorov-Smirnov test of the equality of the two distributions returns a p-value of 0.12 .
} 
by occupation, gender and wave/year, we follow Bruhn and McKenzie (2009) and include the strata dummies year ${ }_{i t}^{k}, M_{i} \times y_{e a r}^{k}$, and $M_{i} \times B_{i} \times y a r_{i t}^{k}$, where $M_{i}$ is an indicator equal to 1 for men and $B_{i}$ is an indicator equal to 1 for bicycle-taxis (bodas).

We then add in interaction terms between the treatment and the occupation/gender cells:

$$
\begin{aligned}
Y_{i t}= & \alpha_{2}+\beta_{2} T_{i t}+\gamma_{2} T_{i t} \times V_{i}+\delta_{2} T_{i t} \times B_{i}+X_{i}^{\prime} \phi_{2} \\
& +\sum_{k=07,09}\left(\theta_{2} \text { year }_{i t}^{k}+\vartheta_{2} M_{i} \times \text { year }_{i t}^{k}+\lambda_{2} M_{i} \times B_{i} \times \text { year }_{i t}^{k}\right)+\varepsilon_{2 i t}
\end{aligned}
$$

where $V_{i}$ is an indicator equal to 1 if the respondent is a male market vendor and, as above, $B_{i}$ is an indicator equal to 1 if the respondent is a boda (all of whom are males).

In this specification, the coefficient $\beta_{2}$ measures the average effect of being assigned to the treatment group for women; the sum $\beta_{2}+\gamma_{2}$ measures the average effect of being assigned to the treatment group for male vendors, and the sum $\beta_{2}+\delta_{2}$ measures the average effect of being assigned to the treatment group for male bicycle-taxi drivers. Given the random assignment to treatment, $E\left(\varepsilon_{2 i t} \mid T_{i t}\right)=0$, and OLS estimates of $\beta_{2}, \gamma_{2}$, and $\delta_{2}$ will be unbiased as long as attrition is not differential. As discussed earlier, since attrition was differential for bodas, our estimates of $\delta_{2}$ may be biased.

Finally, we estimate the average effect of actively using the account using an instrumental variable approach. Specifically, we instrument "actively using the account" with being assigned to the treatment group:

$$
\begin{aligned}
A_{i t}= & a+b T_{i t}+c T_{i t} \times V_{i}+d T_{i t} \times B_{i}+X_{i}^{\prime} \phi_{3}+\omega_{i t} \\
Y_{i t}= & \alpha_{3}+\beta_{3} A_{i t}+\gamma_{3} A_{i t} \times V_{i}+\delta_{3} A_{i t} \times B_{i}+X_{i}^{\prime} \phi_{3} \\
& +\sum_{k=07,09}\left(\theta_{3} \text { year }_{i t}^{k}+\vartheta_{3} M_{i} \times \text { year }_{i t}^{k}+\lambda_{3} M_{i} \times B_{i} \times \text { year }_{i t}^{k}\right)+\varepsilon_{3 i t}
\end{aligned}
$$

where $A_{i t}$ is an indicator of whether individual $i$ actively used the account in year $t$, which we define as having made at least 2 deposits within 6 months. The very strong first stage for the IV estimation is presented in the first two columns of Table $2 .{ }^{24}$ Overall, $41 \%$ of the treatment group actively used the account.

In all the tables that follow, Panel A presents the ITT estimates, Panel B presents the ToT estimates, and Panel $\mathrm{C}$ presents the means and standard deviations of the dependent variables. For both the ITT and ToT estimates, and for each type of individuals in our

\footnotetext{
${ }^{24}$ In a previous version of this paper, we used a weaker definition for actively using the account (making at least one deposit). We adopt a stronger approach here because it would be hard to benefit from using the account only once, unless simply having an account affected an individual's ability to refuse requests for money (e.g., by pretending the money is in the bank and inaccessible, even if is not). In any case, IV results look very similar with the weaker definition of actively using the account (results available upon request).
} 
sample, the p-value for the test that the treatment effect is zero is provided at the bottom of the panel. All regressions include the following baseline covariates: marital status, number of children, age, literacy status, ROSCA contributions in the last year, the stratification cells (gender/ occupation / wave), and the share of days the log was filled in correctly.25

As might be expected, the data from the logbooks is relatively noisy. While most of our main outcomes are not particularly sensitive to extreme values, business outcomes are. For this reason, we present investment outcomes with and without trimming of the top $5 \%$ of values.26

Finally, all the effects for male vendors are very imprecisely estimated due to the very limited size of that subgroup. The confidence intervals for male vendors include both zero and very large effects, and to avoid putting unwarranted weight on these figures, we do not show the coefficient estimates for the interaction between treatment and male vendor $\left(\gamma_{2}\right.$ and $\left.\gamma_{3}\right)$.

\subsection{Impact on Savings}

Table 2 presents the effects of the account on savings. Columns 1-2 show the "first stage": the impact of the treatment on being an "active" account user, where we define active as having made at least two deposits onto the account within the first 6 months of account opening. Unsurprisingly, we find very large first stage effects of the treatment assignment.

We then turn to total amounts saved. Columns 3-4 show results for savings in a bank (as measured from the logbook), and the remaining columns measure whether bank savings crowded out other types of savings (animals in Columns 5-6 and ROSCA contributions in Columns 7-8).27

Reported average daily bank savings are significantly higher in the treatment group (column 3), but the treatment effect is heterogeneous (column 4): there is an increase for market women, but not for bodas. Market women who accessed an account did not decrease their savings in animals or ROSCAs (if anything, they increased their animal stock), therefore their total savings appear to have increased significantly thanks to the treatment.

\footnotetext{
${ }^{25}$ The mean of this variable is $95.0 \%$, with a standard deviation of $8.8 \%$. Reassuringly, this variable does not differ between the treatment and the control groups.

${ }^{26}$ Noise in measures of business outcomes is a common issue in studies of small firms. See, for example, de Mel et al., 2009a, 2009b and McKenzie and Woodruff, 2008.

${ }^{27}$ Animal savings are measured as animal purchases less sales, and ROSCA contributions are measured as contributions less payouts.
} 


\subsection{Impact on Business Outcomes}

Table 3 presents estimates of the effect of the accounts on labor supply and business outcomes. Business investment for vendors is mostly in the form of inventory, but also includes transportation costs associated with traveling to various market centers or shipping goods. Investment for bicycle taxi drivers includes small improvements and repairs to their bicycles 28

We find no effect of the account on labor supply, measured as the average number of hours worked per day. However, we find a large effect of the account on the average daily amount invested in the business, significant at the $10 \%$ level. We find that treated respondents increase investment by $180 \mathrm{Ksh}$, on a base of just $300 \mathrm{Ksh}$, While the overall point estimate is only of marginal significance, it is extremely large (equivalent to a $60 \%$ increase in investment). Given that many people in the treatment group did not use the account, the IV estimate of the effect on active users is even larger ( $425 \mathrm{Ksh}$, or over a $100 \%$ increase). As with the effect on overall savings, this effect is concentrated among market women, though the treatment effect is not statistically significant at conventional levels for them alone (due to the smaller sample size in that group).

Columns 5 and 6 show the results when the business investment data is trimmed. Trimming of course lowers the mean of the dependent variable. It also attenuates the treatment effect, suggesting that most of the very large values are in the treatment group (as would be expected). Even this conservative estimate shows a very large effect for market women: the average daily investment of female vendors in the treatment group is $90 \mathrm{Ksh}(\$ 1.28)$ higher than that of female vendors in the control group (with a p-value of 0.14). Given the baseline average of $240 \mathrm{Ksh}(\$ 3.43)$ in the control group, this effect is equivalent to a $37.5 \%$ increase in investment. Again, the IV estimate is extremely large.

Overall, these results suggest that the treatment had a substantial effect on market women's ability to invest in their business. This is especially noteworthy given that only a minority of women used the accounts - the effect for those that actually used the accounts is extremely large. Thus, while it is important to further investigate these results in future work with bigger samples and more precise estimates, our results suggest potentially very large effects on business outcomes.

Interestingly, this increase in investment for women does not appear to come from a change in business type: we see no change in the category of items traded by women in the treatment group. We also did not observe a change in the scale (retail vs. wholesale) of businesses among women in the treatment group. This means that the market women who

\footnotetext{
${ }^{28}$ All bodas in our sample already owned their bike at baseline.
} 
benefited from the account simply purchased more from the wholesaler.

We also find an increase in revenues among market women (columns 7-10), but as discussed above, the amounts reported as revenues are typically smaller than the amounts reported for investments, and all in all taking the difference between the treatment impacts on revenues and investments would suggest that the treatment reduced profits for market women. We do not consider this as likely. Rather, it seems that revenues were systematically under-reported and this under-reporting was magnified in the treatment group.

\subsection{Impact on Expenditures and Transfers}

Table 4 presents estimates of the impact on the average expenditures reported in the logbooks. The first six columns present total, food, and private expenditures (private expenditures include meals in restaurants, sodas, alcohol, cigarettes, own clothing, hairstyling, and entertainment expenses).

We find a positive overall treatment effect. The point estimate for total expenditures is positive, though the p-value is only 0.13. More disaggregated expenditure categories reveal large increases for some items. Across the whole sample, food expenditures increased by $13 \%$ while private expenditures increased by $38 \%$. These imply even larger effects for account users (of $32 \%$ and $93 \%$, respectively). ${ }^{29}$ As in the previous tables, these effects are driven by market women.

The last four columns of Table 4 look at the impacts on transfers to and from others. Transfers include both cash and in-kind transfers of goods and services (as valued by the respondent). We look at net transfers to individuals outside the household and net transfers to the spouse (for married/cohabiting respondents). The point estimates suggest a decrease in net transfers outside the household and no effect on inter-spousal transfers, but the results are very imprecise, with large standard errors, and even for inter-household transfers we cannot reject the null of zero effect.

\subsection{Robustness Checks}

There are several possible threats to the internal validity of this study. In the Appendix, we consider two potentially important concerns: (1) that the results might be driven by people who were anticipating a later loan from the village bank, and (2) that the results might be driven by people making large deposits (who presumably do not have a problem saving in

\footnotetext{
${ }^{29}$ The returns to capital would have to be implausibly large for this increase in expenditure to be entirely due to an increase in business income. Given this, the increase in expenditure likely comes from both an increase in income and an increase in the ability to shield income from others.
} 
the first place since they deposit so much at any one time). We find no evidence for either of these alternatives, and so we feel confident that our main results reflect the impact of savings services alone for people who otherwise find it hard to save as much as they would like.

\section{Discussion of Potential Mechanisms}

Overall, our results show that the informal savings mechanisms available in rural Kenya are ineffective in allowing a sizeable fraction of market women to save (and subsequently invest) as much as they would like. These results raise two questions: First, why do market women need a savings account when it seems like they could instead simply reinvest immediately in their business - why do they put money into the savings account at all? Second, why is the private return to informal savings so highly negative for a large fraction of the market women in our sample? Since our data does not enable us to conclusively answer these questions, we instead use this section to make some conjectures as to possible answers and areas to further investigate.

With regards to the first question, we see three possible reasons why business owners may have to save at home or in a bank account, even if the returns are negative, rather than continuously reinvest in their business. The first is that investment may be lumpy, so that entrepreneurs cannot reinvest in their business until they have saved up for the next discrete unit. Instead, they must save outside of the business for some time before they can reinvest ${ }^{30}$ The second is that business profits may be variable, but at least partially foreseeable by entrepreneurs, so that there are periods in which it is optimal to save money outside the business. The third is that it might not be possible to quickly and costlessly liquidate working capital if a shock were to occur. If people face credit constraints, the liquidity costs of holding capital uniquely in the business might make it necessary for people to save against unanticipated shocks (such as illness) outside the business.

With regards to the second question, we see two broad explanations for why market women in our sample could not save enough without formal savings devices. First, these women may have present-biased preferences, and thus may be tempted to spend any cash money that they hold (Laibson, 1997; Gul and Pesendorfer, 2001; Gul and Pesendorfer, 2004). Second, these women may face regular demands on their income from relatives or

\footnotetext{
${ }^{30}$ For this channel to be at play, deposits have to be smaller than the investment "lump". To check this, Figure 3 plots a CDF of average deposits, withdrawals, and investment (excluding zeros) for market women in our sample. Average deposits are clearly dominated by investment (and investment is dominated by withdrawals). This suggests that market women in our sample saved up relatively small amounts to deposit, and then withdrew in bigger sums.
} 
neighbors (Platteau, 2000), or from their husbands (Ashraf, 2009). In either case, keeping money at the bank where it is not immediately accessible might increase total savings.

Both phenomena have been shown to be at play in our study area. Duflo, Kremer and Robinson (2011) show that time-inconsistent preferences limit profitable investments in fertilizer by farmers in Western Kenya. Also in Western Kenya, Dupas and Robinson (2012) show that money demands from others form an important barrier to preventative health investments. However, the effectiveness of a savings product in overcoming these two barriers depends on the type of commitment or earmarking it provides. In Dupas and Robinson (2012), we show that, while pressure to share with others can be somewhat overcome with a simple savings technology such as a box with a lock and key, overcoming timeinconsistent preferences requires a savings technology with a strong commitment feature, such as a ROSCA.

Which of these two barriers mattered in our sample? The way accounts were used provide some insights. The frequency of transactions was relatively low, and the median deposit size was relatively large (the average deposit size for the median woman who actively used the account was equivalent to about 1.6 days of average expenditures.) This, combined with the fact that the bank closed at 3pm (well before work ends for most market vendors), makes it clear that market women did not build up savings balances by depositing small amounts of money every night after work, but instead saved up for some time and then deposited larger sums. This suggests that the basic savings accounts provided in the study were not likely to be useful to solve a hyperbolic discounting problem. Rather, market women may have been using the accounts to protect their income from demands from friends and family. For instance, women may get asked for money by extended family and may feel socially obligated to give something if the money is readily accessible, but these requests might be relatively infrequent (every few weeks, for example). If so, and if it is costly (in terms of time and effort) to go to the bank, it may be rational to only go to the bank every few weeks, rather than every day:31

To provide further evidence on potential mechanisms, Table 5 looks at determinants of account usage. We restrict the sample to those ever offered an account, and regress the $\log$

\footnotetext{
${ }^{31}$ In qualitative surveys, people report that it is easier to say "no" to friends and relatives asking for money when the money is saved in a bank than when money is saved in the house. This suggests that generosity towards friends and relatives might often be "involuntary" - people give money to avoid having to lie about money availability (to avoid a feeling of guilt) but if the money is truly not available at home, people do not feel guilty saying they have no money available. This is consistent with lab experiments showing that, in dictator games, dictators are willing to sacrifice part of the total prize to opt out of the game, provided that the decision is not revealed to recipients (Dana, Cain and Dawes, 2006). This opting-out behavior is particularly common among dictators who appear "generous" when the silent opt-out option is not available (Broberg, Ellingsen, and Johannesson, 2007), suggesting that guilt or shame, rather than altruism, is at the source of the high generosity levels typically observed in dictator games.
} 
of the sum of total deposits in the first six months on baseline characteristics. To include those who made no deposits, we add one to the sum of total deposits, such that for those who made zero deposit the dependent variable is zero. The coefficients on female vendor is large and significant (relative to the omitted category - bodas) ${ }^{32}$ but its magnitude (and even sign) change as covariates are added, suggesting that the female vendor effect can be explained by observable characteristics. In particular, usage is very strongly positively correlated with ROSCA participation, which is higher among female vendors ${ }^{33}$ Account usage is also very strongly correlated with wealth (measured in the value of animals and durable goods owned), suggesting that the accounts were mostly useful for people somewhat further above subsistence.

We include controls for risk and time preferences in Column 3 of Table $5{ }^{34}$ Risk aversion is correlated with usage: less risk-averse individuals were less likely to use the accounts, pointing to a possible consumption smoothing rationale for usage. More patient people appear more likely to save, although the effect is insignificant. In terms of the time consistency measures, we find that respondents who exhibit present-biased preferences were not more likely to deposit money than the omitted time-consistent group. This is not surprising since the savings account we subsidized offered a commitment device to avoid spending money once it had been deposited, but was not accompanied by a commitment to make regular deposits. Present-biased individuals might have had a difficult time committing themselves to making regular trips to the bank.

\footnotetext{
${ }^{32}$ Note that a dummy for male vendor is included in this regression but the coefficient is not shown.

${ }^{33}$ Given the correlation between ROSCA participation and active use of the account, the fact that ROSCA contributions among market women were not crowded out by the accounts (Table 2) could be surprising, especially since savings are more quickly and reliably accessible when placed in a formal account than with a ROSCA. We can think of various possible explanations for why this is the case, however. First of all, ROSCA cycles can be long (up to 18 months), so our data might be too medium-run to capture changes in participation. Secondly, ROSCAs typically offer more than just savings to their participants. In particular, many ROSCAs offer loans (in addition to the regular pot) to their participants, and often also provide some emergency insurance. A census of ROSCAs we conducted in the area of study suggests that $64 \%$ of ROSCAs offer loans to their members, and $54 \%$ offer insurance in case of a funeral or other catastrophic events (Dupas and Robinson, 2012). Finally, while bank savings are made individually, ROSCA contributions are made in a group. The social aspect of ROSCAs may provide some form of commitment, either through social pressure to keep contributing (Gugerty, 2007) or from the regular schedule of payments. For these reasons, a formal savings account might only be an imperfect substitute for ROSCA participation.

${ }^{34}$ As discussed earlier, note that these measures should be taken with some caution as they were measured ex-post for a large part of the sample.
} 


\section{Conclusion}

The experiment described in this paper provides strong evidence that a sizeable fraction of micro-entrepreneurs in rural Kenya face major savings constraints. These constraints are so strong that around $40 \%$ of market women decided to take up savings accounts which offered a negative real interest rate. This result suggests that the alternative savings opportunities that market women face offer an expected return even more negative.

Market women use these accounts to save up to increase the size of their business and increase their private expenditures. However, the accounts had minimal effects for the other group of daily income earners in our sample (bicycle-taxi drivers), who did not use the accounts at all. One interpretation of this finding is that these men were able to save at home more securely, and so did not need accounts with such low returns. However, we prefer not to draw any conclusions regarding that subgroup, because there was differential attrition between the treatment and control arms among them, and we cannot rule out that there were differences in unobservable characteristics between the two arms.

Given the large impacts we estimate for at least a third of the market women in our sample, a natural question is why market women did not open up accounts on their own, prior to our study. This seems to be because the bank we worked with (the only bank in town) was relatively new and poorly known at baseline. This is consistent with recent evidence that levels of familiarity with and trust in financial institutions are relatively low in rural Kenya, due to a long history of financial scandals of various sorts, as well as unreliable service provision (Dupas et al., 2012). The bank we partnered with was reliable, however, and therefore take-up of accounts should have increased over time. Indeed, the number of account holders at the bank increased by $200 \%$ between 2007 and 2011, from around 1,300 to 4,000 .

Overall, our findings suggest that extending basic banking services could have large effects at relatively small cost, especially relative to credit alone. However, there are several major caveats to this result. The most important is that our sample is relatively small and composed entirely of two specific types of income earners, so more work needs to be done to examine whether the results generalize to other individuals in other settings.

Another important caveat is that while we document savings constraints at the individual level, the general equilibrium effects of extending savings to the entire unbanked population

remain unclear. It is possible that the market women in our treatment group grew their business at the expense of neighboring businesses. Even beyond this, the accounts could have changed the nature of informal insurance networks. For example, if informal insurance is constrained by a limited commitment constraint, the accounts could have changed par- 
ticipation in informal insurance by affecting the value of autarky for treatment individuals (Ligon, Thomas, and Worrall, 2000). To estimate such general equilibrium effects, one would have to randomize access to financial services at the village level (rather than the individual level), or to exploit gradual expansion of formal saving services across villages (which is difficult since bank expansion typically brings both saving and credit services at the same time, as in Burgess and Pande, 2005, or Bruhn and Love, 2009). This is outside the scope of this study, which aimed to first establish the extent to which saving constraints are binding at the individual level, but we believe that studying the importance of savings constraints at a more aggregate level is an important issue for future work.

Our findings also raise a number of issues about the pathways through which formal bank accounts helped market women in our sample. First, are the savings constraints implied by our results due primarily to social pressure to share resources, or to self-control problems? Second, to what extent do intra-household (inter-spousal) conflicts in preferences explain our results?

Finally, a particularly important question is why more than half of the individuals in the treatment group did not actively take up these accounts. Is it because they do not have savings problems, or is it because this particular saving device was not well suited to their needs, for example because it did not offer a strong commitment feature? One clue is that $92 \%$ of those that were offered accounts but who did not actively use them report that "it is hard to save at home," which suggests that they, too, face barriers to savings. Given the dearth of savings and credit opportunities currently available in sub-Saharan Africa, more work is needed to understand which saving services or devices are best suited to these individuals. 


\section{References}

[1] Aggarwal, Shilpa, Leora Klapper and Dorothe Singer (2011). "Financing Businesses in Africa: The Role of Microfinance." Working paper, World Bank.

[2] Aportela, Fernando (1999): "Effects of Financial Access on Savings by Low-Income People." mimeo, Banco de México.

[3] Ashraf, Nava (2009): "Spousal Control and Intra-Household Decision Making: An Experimental Study in the Philippines." American Economic Review 99(4): 1245-1277.

[4] Ashraf, Nava, Dean S. Karlan and Wesley Yin (2006): "Tying Odysseus to the Mast: Evidence from a Commitment Savings Product in the Philippines." Quarterly Journal of Economics, 121(2): 635-672.

[5] Attanasio, Orazio, Britta Augsburg, Ralph De Haas, Emla Fitzsimons and Heike Harmgart (2012). "Group Lending versus Individual Lending in Mongolia." Working paper.

[6] Banerjee, Abhijit, Duflo, Esther, Rachel Glennerster, and Cynthia Kinnan (2009): "The Miracle of Microfinance? Evidence from a Randomized Evaluation." mimeo, MIT.

[7] Bauer, Michal, Julie Chytilová, and Jonathan Morduch (2010): "Behavioral Foundations of Microcredit: Experimental and Survey Evidence." IZA Discussion Paper No. 4901.

[8] Broberg, T., T. Ellingsen, and M. Johannesson (2007): "Is Generosity Involuntary?" Economic Letters, 94, 32-37.

[9] Bruhn, Miriam, and David McKenzie (2009): "In the Pursuit of Balance: Randomization in Practice in Development Field Experiments". American Economic Journal: Applied Economics 1(4): 200-232.

[10] Bruhn, Miriam, and Inessa Love (2009): "The economic impact of banking the unbanked: evidence from Mexico". World Bank Policy Research working paper no. 4981.

[11] Burgess, Robin and Rohini Pande (2005): "Do Rural Banks Matter? Evidence from the Indian Social Banking Experiment." American Economic Review 95 (3): 780-795.

[12] Chaia, Alberto, Aparna Dalal, Tony Goland, Maria Jose Gonzalez, Jonathan Morduch, and Robert Schi (2009). "Half the World is Unbanked." Financial Access Initiative Framing Note.

[13] Charness, Gary and Garance Genicot (2009): "Informal Risk Sharing in an InfiniteHorizon Experiment." Economic Journal 119 (537): 796-825. 
[14] Cole, Shawn A., Thomas Sampson, and Bilal Zia (2011). "Prices or Knowledge? What Drives Demand for Financial Services in Emerging Markets?" Journal of Finance 66 (6): $1933-1967$.

[15] Collins, Darryl, Jonathan Morduch, Stuart Rutherford, and Orlando Ruthven (2009). Portfolios of the Poor: How the World's Poor Live on Two Dollars a Day. Princeton University Press.

[16] Crépon, Bruno, Florencia Devoto, Esther Duflo and William Parienté (2011). "Impact of Microcredit in Rural Areas of Morocco: Evidence from a Randomized Evaluation." Mimeo, MIT.

[17] Dana, J., D. M. Cain, and R. M. Dawes (2006): "What You Don't Know Won't Hurt Me: Costly (But Quiet) Exit in Dictator Games," Organizational Behavior and Human Decision Processes, 100, 193-201.

[18] Daniels, Lisa (2001): "Testing Alternative Measures of Microenterprise Profits and Net Worth." Journal of International Development 13: 599-614.

[19] de Mel, Suresh, David McKenzie and Christopher Woodruff (2008): "Returns to Capital in Microenterprises: Evidence from a Field Experiment." Quarterly Journal of Economics 123(4): 1329-1372.

[20] de Mel, Suresh, David McKenzie and Christopher Woodruff (2009a): "Measuring Microenterprise Profits: Must We Ask How the Sausage Is Made?" Journal of Development Economics 88(1): 19-31.

[21] de Mel, Suresh, David McKenzie, and Christopher Woodruff (2009b): "Are Women More Credit Constrained? Experimental Evidence on Gender and Microenterprise Returns" American Economic Journal: Applied Economics 1(3): 1-32.

[22] de Soto, Hernando (1989). The Other Path: The Invisible Revolution in the Third World, New York, NY: Harper and Row.

[23] Duflo, Esther, Michael Kremer and Jonathan Robinson (2011). "Nudging Farmers to Use Fertilizer: Theory and Experimental Evidence from Kenya." American Economic Review 101 (6): 2350-2390.

[24] Dupas, Pascaline, and Jonathan Robinson (2012)."Why don't the Poor Save More? Evidence from Health Savings Experiments in Kenya". Mimeo, UCLA.

[25] Dupas, Pascaline, Sarah Green, Anthony Keats, and Jonathan Robinson (2012). "Supply and Demand Challenges in Banking the Rural Poor: Evidence from Kenya." Forthcoming, NBER Africa Project Conference Volume. 
[26] Gugerty, Mary Kay (2007): "You can't save alone: Commitment in Rotating Savings and Credit Associations in Kenya", Economic Development and Cultural Change 55: 251-282.

[27] Gul, Faruk and Wolfgang Pesendorfer (2001), "Temptation and Self-Control", Econometrica 69(6): 1403-1435.

[28] Gul, Faruk and Wolfgang Pesendorfer (2004): "Self-Control and the Theory of Consumption," Econometrica 72(1): 119-158.

[29] International Monetary Fund (2010): World Economic Outlook Database. Available online at http://www.imf.org/external/pubs/ft/weo/2010/01/weodata/index.aspx.

[30] Johnston, Don Jr. and Jonathan Morduch (2008): "The Unbanked: Evidence from Indonesia," World Bank Economic Review 22 (3): 517-537.

[31] Kaboski, Joseph and Robert Townsend (2005): "Policies and Impact: An Analysis of Village-Level Microfinance Institutions," Journal of the European Economic Association 3(1): 1-50.

[32] Kaboski, Joseph and Robert Townsend (2011): "A Structural Evaluation of a LargeScale Quasi-Experimental Microfinance Initiative." Econometrica 79 (5): 1357-1406.

[33] Karlan, Dean and Jonathan Zinman (2010a): "Expanding Credit Access: Using Randomized Supply Decisions To Estimate the Impacts" Review of Financial Studies 23(1): 433-46.

[34] Karlan, Dean and Jonathan Zinman (2010b): "Expanding Microenterprise Credit Access: Using Randomized Supply Decisions to Estimate the Impacts in Manila." mimeo, Dartmouth and Yale.

[35] Kendall, Jake, Nataliya Mylenko and Alejandro Ponce (2010). "Measuring Financial Access around the World." World Bank Policy Research Working Paper 5253.

[36] Laibson, David (1997): "Golden Eggs and Hyperbolic Discounting," Quarterly Journal of Economics 112(2): 443-477.

[37] Liedholm, Carl (1991): "Data Collection Strategies for Small-scale Industry Surveys", GEMINI Working Paper No. 11, Bethesda, MD: Development Alternatives, Inc.

[38] Ligon, Ethan, Jonathan P. Thomas, and Tim Worrall (2000): "Mutual Insurance, Individual Savings, and Limited Commitment," Review of Economic Dynamics 3 (2): 216-246.

[39] McKenzie, David and Christopher Woodruff (2008): "Experimental Evidence on Returns to Capital and Access to Finance in Mexico." World Bank Economic Review 
22(3): 457-482.

[40] Platteau, Jean-Philippe (2000): "Egalitarian Norms and Economic Growth." In Institutions, Social Norms and Economic Development. Amsterdam, Harwood Academic Publishers.

[41] Rutherford, Stuart (2000): The Poor and Their Money. Oxford, UK: Oxford University Press.

[42] Thaler, Richard H. and Shlomo Benartzi (2004): "Save More Tomorrow: Using Behavioral Economics to Increase Employee Saving," Journal of Political Economy 112(1): S164-187.

[43] Strauss, John and Duncan Thomas (1995): "Human Resources: Empirical Modeling of Household and Family Decisions", in J. Behrman \& T.N. Srinivasan (ed.), Handbook of Development Economics, volume 3A, chapter 34, 1883-2023. Amsterdam: NorthHolland Press.

[44] World Bank (2004): World Bank Development Report 2005: A Better Investment Climate - for Everyone, New York, NY: World Bank and Oxford University Press. 
Figure 1. Number of transactions at village bank in first 6 months

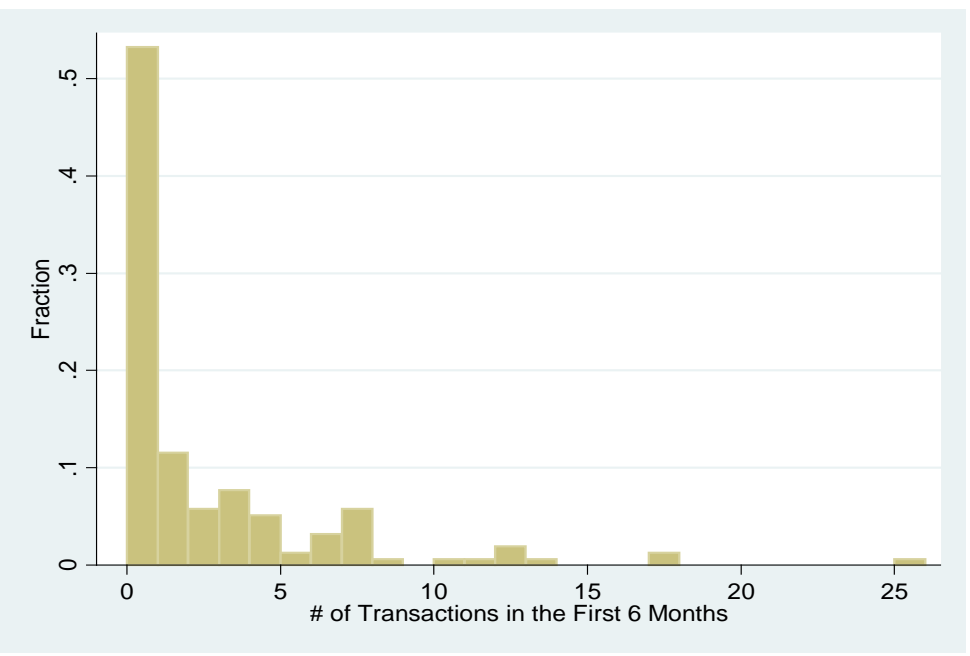

Figure 2. CDFs of Total Amount Deposited in First 6 Months

Panel A: CDF of Deposits in First 6 Months, Below 75th Percentile

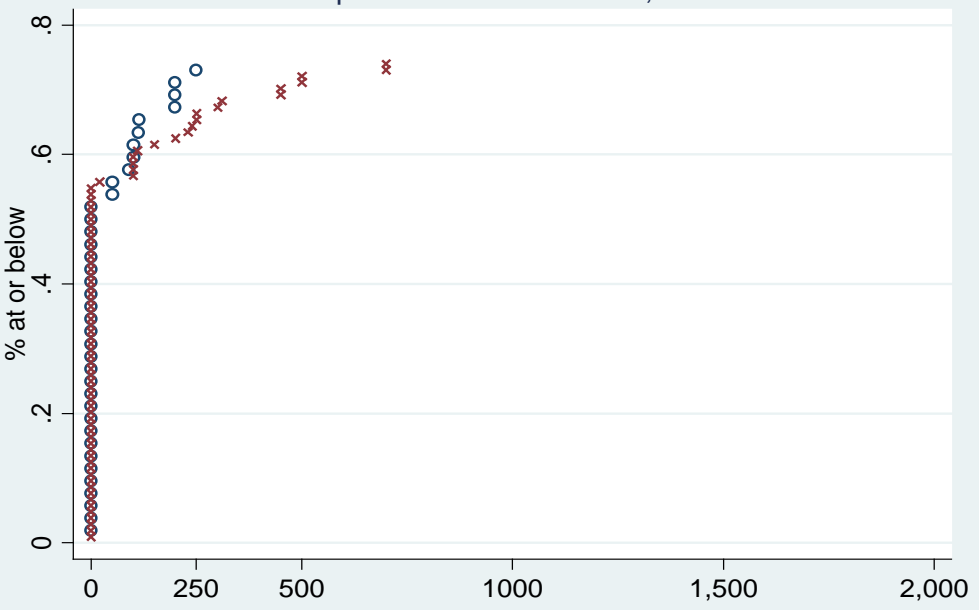

Panel B: CDF of Deposits in First 6 Months, Above 75th Percentile

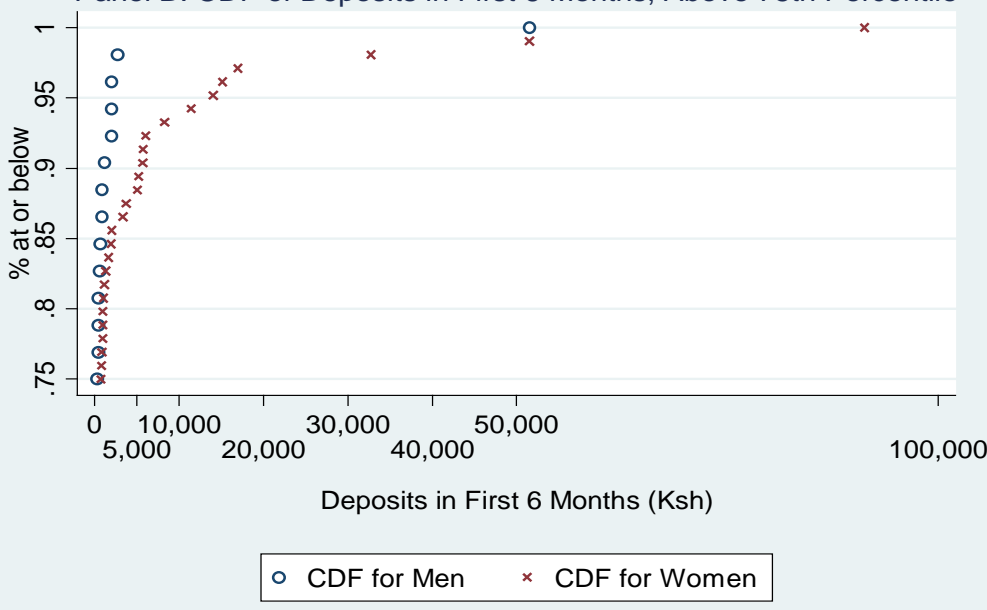

Notes: Data from 156 individuals offered an account. Those who refused to open an account are coded as having 0 transactions (Figure 1) and 0 deposits (Figure 2). The sample mean of the total deposited in the first six months is 2,500 Ksh. The mean among those with a non-zero total is 5,000 Ksh (median: $700 \mathrm{Ksh}$ ). 
Figure 3. CDFs of Deposits, Withdrawals, and Investment (in Ksh) for Female Vendors

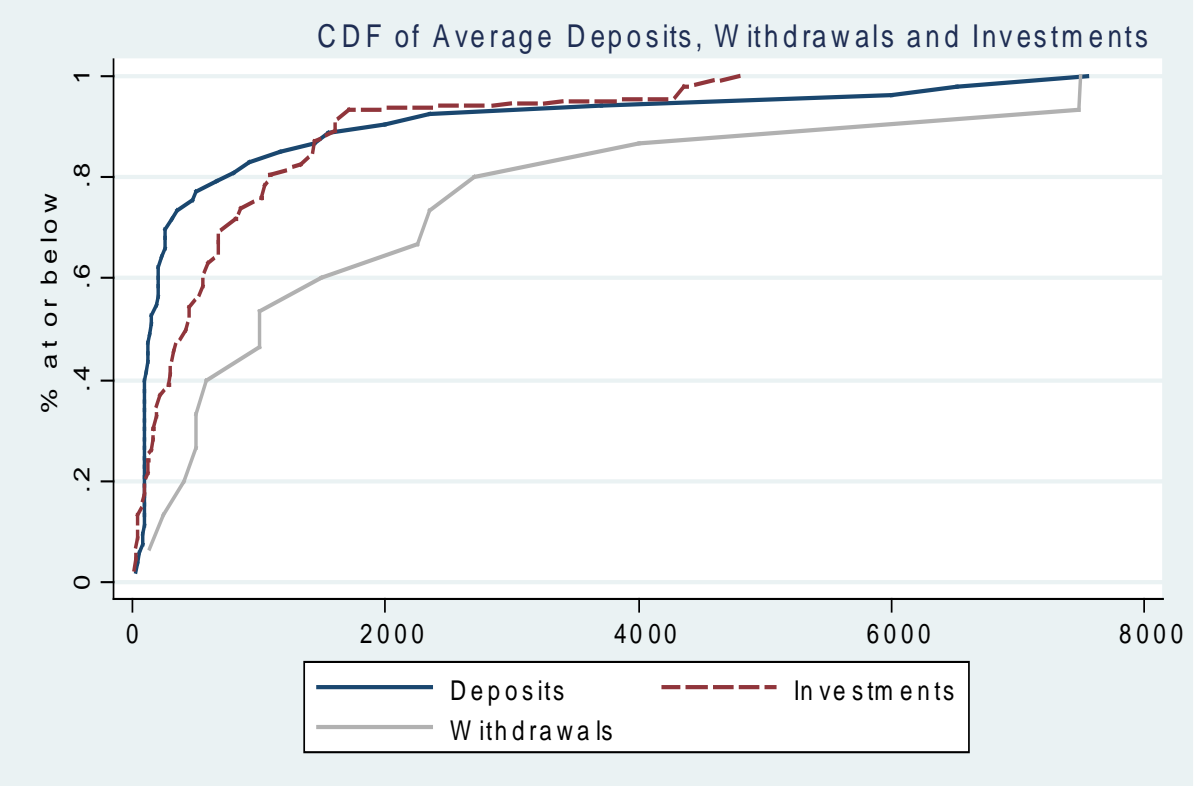

Notes: Figure shows average deposits, withdrawals, and investments for female vendors in the treatment group. 


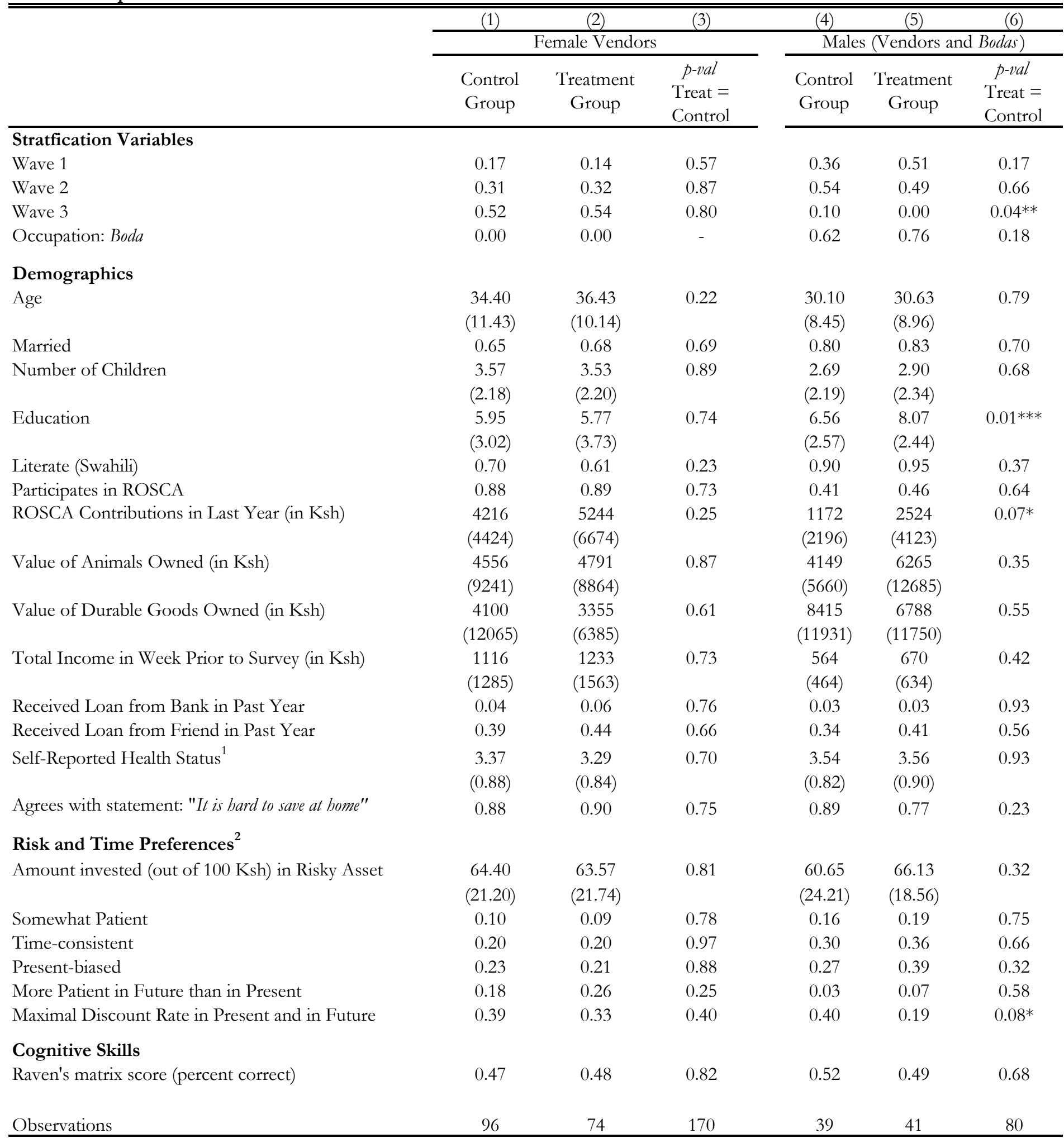

Notes: Sample restricted to respondents for whom we have logbook data. Columns 1, 2, 4 and 5 report means, with standard deviations in parentheses. Columns 3 and 6 report p-values obtained when testing the hypothesis that the difference between the treatment and the control means is equal to 0 . P-values under $0.1,0.05,0.01$ are highlighted with ***,*** respectively. Exchange rate was roughly $70 \mathrm{Ksh}$ to US $\$ 1$ during the study period.

${ }^{1}$ Health Status is coded as: 1-very poor, 2-poor, 3-just OK, 4-good, 5-very good.

${ }^{2}$ The risky asset paid off 4 times the amount invested with probability 0.5 , and 0 with probability 0.5 . "Somewhat Patient" is a dummy equal to 1 if the respondent prefers $55 \mathrm{Ksh}$ (or less) in a month to $40 \mathrm{Ksh}$ now. "Time Consistent" is a dummy equal to 1 if the respondent exhibits the same discount rate between today and 1 month from today. "Present-Biased" is a dummy equal to 1 if the respondent exhibits a higher discount rate between today and one month from today than between 1 month from today and two months from today, "More Patient in Future than in Present" is a dummy equal to 1 if the respondent is more patient in 1 month than she is today, and "Maximum Discount Rate in the Present and in the Future" is a dummy equal to 1 if a respondent prefers 40 Ksh today to 500 Ksh in 1 month and 40 Ksh in 1 month to $500 \mathrm{Ksh}$ in 2 months. 
Active Bank

Account Usage

Bank Savings (Ksh)

Animal Savings (Ksh)

Rosca Contributions

("First-Stage")

Panel A. Intention-to-Treat Estimates (ITT)

Sampled for Savings Account

$\begin{array}{ccc}0.41 & 0.40 & 9.36 \\ (0.05)^{* * *} & (0.06)^{* * *} & (3.43)^{* * *}\end{array}$

Sampled for Savings Account * Boda

Observations

$p$-value for overall effect $=0$

$p$-value for effect for female vendors $=0$

$p$-value for effect for bodas $=0$

2

\section{Panel B. Instrumental Variable Estimates (ToT)}

Account is Active

Account is Active $*$ Boda

Observations

$p$-value for overall effect $=0$

$p$-value for effect for female vendors $=0$

$p$-value for effect for bodas $=0$

250

$(0.06) * * *$

$$
\begin{gathered}
0.06 \\
(0.11)
\end{gathered}
$$

$0.01 * * *$

250

11.39
$(4.42)^{* *}$
-12.43
$(6.06)^{* *}$
250

16.79

(Ksh)

$0.01 * * *$

$0.01 * * *$

$0.01 * * *$
$0.01 * * *$

$0.01^{* *}$
0.82

$\begin{array}{cccc}16.79 & 23.26 & 7.81 & 12.57 \\ (10.05)^{*} & (14.03)^{*} & (7.02) & (10.08) \\ & -20.00 & & -12.56 \\ & (17.85) & & (14.10) \\ 250 & 250 & 250 & 250\end{array}$

$0.1 *$

0.27

0.75

0.21

1.00

$\begin{array}{cccccc}22.82 & 28.77 & 40.91 & 58.37 & 19.03 & 31.42 \\ (8.51)^{* * *} & (11.41)^{* *} & (24.41)^{*} & (35.09)^{*} & (17.08) & (25.11) \\ & -29.35 & & -49.40 & & -30.57 \\ & (13.88)^{* *} & & (40.88) & & (31.87) \\ 250 & 250 & 250 & 250 & 250 & 250 \\ & & & & & \\ 0.01 * * * & & 0.1 * & & 0.27 & \\ & 0.01 * * & & 0.1 * & & 0.21 \\ & 0.95 & & 0.67 & & 0.96\end{array}$

Panel C. Mean and Std. Dev. of Dependent Variable in Control Group

Entire Sample: Mean

$$
\text { Std. Dev. }
$$

-1.95
30.29

3.81

26.30

30.29

9.16

35.46

Female Vendors: Mean

Bodas:

Std. Dev.

Mean

$-2.33$

33.78

3.96

16.61

Notes: Dependent variables are daily averages. Dependent variables expressed in Kenyan shillings. Controls include occupation, ROSCA contributions in year before baseline, marital status, number of children, age, literacy, the number of weeks in the diary data, and the wave / type stratification cells. Evennumbered colums also include an interaction term between "Sampled for Savings Account" and "Male Vendor". The first-stage for the IV estimations in Panel B are presented in Panel A, columns 1-2.

Exchange rate was roughly $70 \mathrm{Ksh}$ to US $\$ 1$ during the study period.

Standard errors in parentheses. $*$ significant at $10 \%$; ** significant at $5 \%$; *** significant at $1 \%$. 


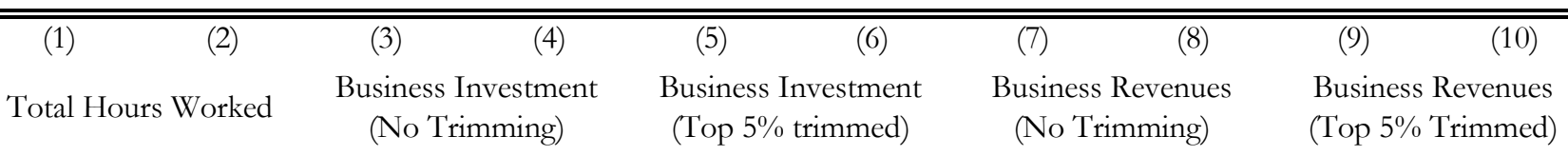

Panel A. Intention-to-Treat Estimates (ITT)

Sampled for Savings Account

Sampled for Savings Account* Boda

$\begin{array}{llll}0.15 & 0.31 & 179.71 & 203.23\end{array}$

Observations

$(0.37)$

$(0.44) \quad-179.71 \quad 203.23$

87.37

No Trimming)

Top 5\% Trimmed)

$p$-value for overall effect $=0$

$p$-value for effect for female vendors $=0$

$(0.44)$

$(105.17)^{*}$

$(147.63)$
-97.03

$(46.91)^{*}$

90.43

129.32

116.46

58.59

37.59

$(0.88)$

244

(222.92)

$-30.08$

(84.45)

(100.32)

$(133.34) \quad(34.83)^{*}$

(43.62)

$-3.28$

(203.17)

27.70

$249 \quad 249$

$0.09 *$

$p$-value for effect for bodas $=0$

$$
0.49
$$

$$
0.09 *
$$$$
244
$$

244

$(84.45)$
244

241

241

241

(76.40)

Panel B. Instrumental Variable Estimates (ToT)

Account is Active

Account is Active * Boda

$\begin{array}{cc}0.36 & 0.77 \\ (0.91) & (1.12) \\ & -1.31 \\ & (1.94) \\ 249 & 249\end{array}$

Observations

$p$-value for overall effect $=0$

$p$-value for effect for female vendors $=0$

$p$-value for effect for bodas $=0$

0.69

0.17

$0.06^{*}$

0.14

0.34

0.20

$$
0.38
$$

$0.09^{*}$

0.46

0.39

0.30

$\begin{array}{cccc}425.20 & 503.85 & 206.72 & 224.49 \\ (248.32)^{*} & (365.57) & (112.18)^{*} & (154.02) \\ & -258.45 & & -86.73 \\ & (490.29) & & (187.01) \\ 244 & 244 & 244 & 244\end{array}$

304.44

(236.81)

289.71

137.93

(331.59)

$-41.68$

(438.13)

$(83.02)^{*}$

94.20

$0.07 *$

$0.09^{*}$

0.17

0.49
0.74

0.15
0.28

0.20

0.44

0.28

296.83

487.83

191.08

224.20

239.80
222.03
11.30
8.81

343.89

518.63

403.43
560.85
96.68
48.04

197.26

186.23

363.84
471.69

11.30

8.81

8.81

48.04

Notes: see Table 2 notes. 


$\begin{array}{llll}(1) & \text { (2) (3) } & \text { (4) }\end{array}$

Daily Total Expenditure Daily Food Expenditure

\section{(5)}

Expenditure

Net Transfers Outside the Household

Panel A. Intention-to-Treat Estimates (ITT)

Sampled for Savings Account

Sampled for Savings Account* Boda

23.93
$(15.81)$

Observations

250

31.17

$(19.59)$

10.67

$(6.41)^{*}$

14.46

$\begin{array}{cc}8.94 & 7.77\end{array}$

$-12.85$

$(44.42)$

$-7.78$

$(3.75)^{* *}$

$(3.98)^{*}$

(14.40)

$-18.84$

(20.86)

$(15.61)$

5.18
$(11.63)$

(22.65)

250

250

249

249

$p$-value for overall effect $=0$

$0.1^{*}$

$P$-value for effect for female vendors $=0$

0.11

$0.02^{* *}$

$0.09 *$

0.37

$0.05^{*}$

0.24

0.37

0.86

Panel B. Instrumental Variable Estimates (ToT)

Account is Active

Account is Active* Bodo

58.33
$(38.50)$

Observations

$p$-value for overall effect $=0$

$p$-value for effect for female vendors $=0$

$p$-value for effect for bodas $=0$

77.97

$(48.81)$
-30.73

(96.51)

$250 \quad 250$

0.13

Panel C. Mean and Std. Dev. of Dependent Variable in Control Group

$\begin{array}{ll}\text { Entire Sample: } & \text { Mean } \\ & \text { Std. Dev. }\end{array}$

Female Vendors: Mean

Bodas: $\quad$ Std. Dev.

Mean
Std. Dev.

Notes: see Table 2 notes.
163.12

119.69

169.14

117.77

131.21

106.84 $\begin{array}{llll}26.00 & 36.20 & 21.79 & 19.61\end{array}$

$(15.46)^{*}$

36.20
$(21.02)^{*}$

$-21.09$

(33.92)

250

$0.09 *$

0.11

0.56

21.79
$(9.40)^{* *}$

19.61
$(10.18)$
8.62

8.62

250

$0.02^{* *}$

$0.09 *$

0.57

$0.06^{*}$

0.25
(26.12)

82.04

53.87

\begin{tabular}{l} 
\\
86.96 \\
54.96 \\
59.24 \\
31.43 \\
\hline
\end{tabular}

23.33

23.39
$-31.37$

(35.40)

$-47.32$

$(53.01)$
43.53

(54.54)

249

0.38

21.08
23.44
25.12
23.77

6.96

192.44

\begin{tabular}{ccc} 
& -9.02 & \\
& 42.83 & \\
12.03 & & -26.44 \\
228.14 & & 35.68 \\
-0.23 & & 21.50 \\
10.53 & & 18.96 \\
\hline
\end{tabular}

35.68

21.50
18.96
(5.23)

202

0.51

4.16

(9.71)

202

0.20

$9.07 \quad 11.50$

(13.59) (19.48)

4.69

(23.65)

202

0.51

0.56

0.22 
Table 5. Determinants of Account Usage within 6 months of Account Opening

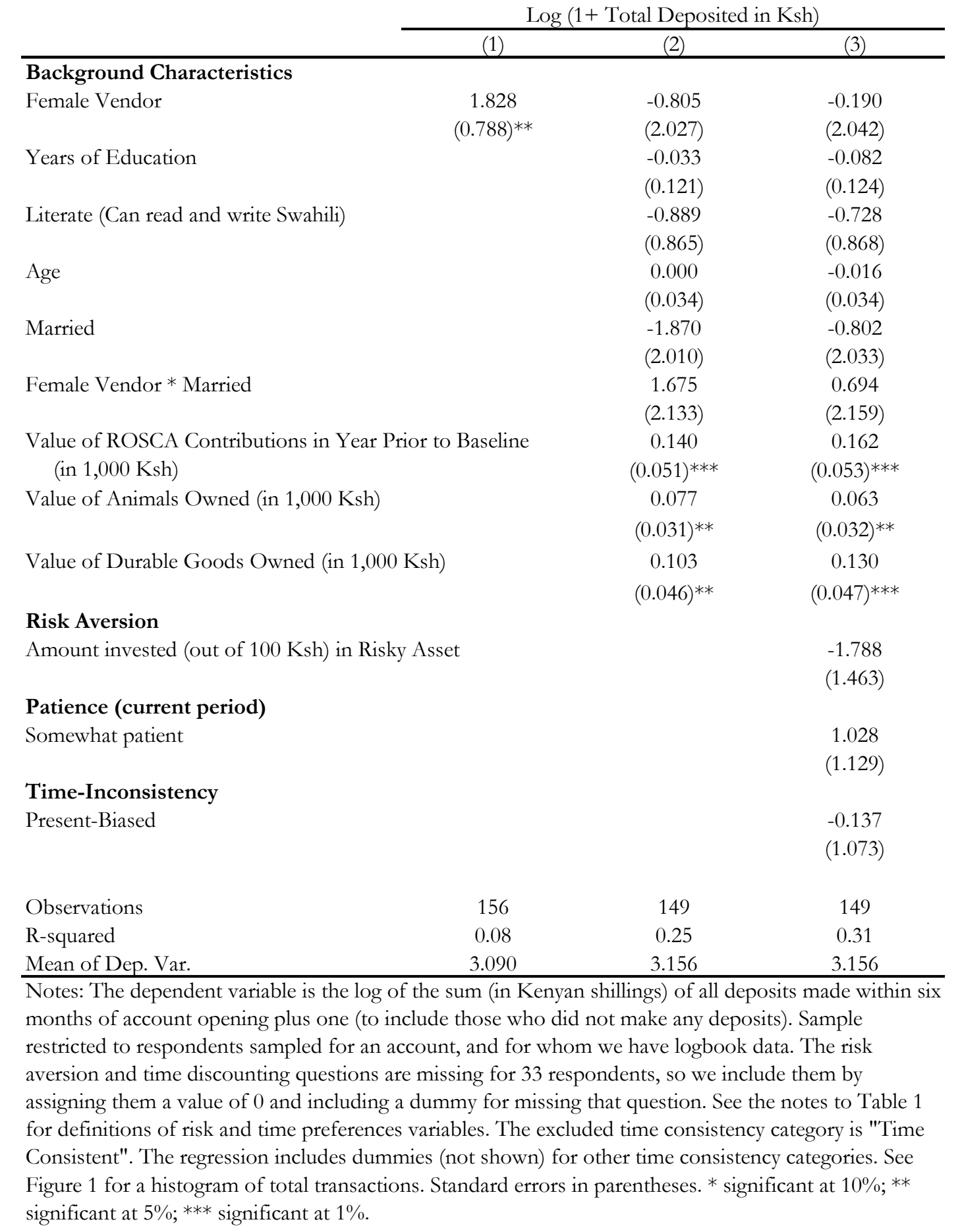




\section{Panel A. Sample Frame: Total number of people interviewed at baseline}

\begin{tabular}{|c|c|}
\hline (1) & (2) \\
\hline $\begin{array}{c}\text { Female } \\
\text { Vendors }\end{array}$ & $\begin{array}{c}\text { Bicycle Taxi } \\
\text { Drivers } \\
\text { ("Bodas") }\end{array}$ \\
\hline
\end{tabular}

\begin{tabular}{cc}
$\frac{(3)}{\text { Male }}$ & \\
Vendors & Total \\
\hline
\end{tabular}

TOTAL

Assigned to Control

262

132

130

\section{6}

34

392

Assigned to Treatment

46

17

197

Wave 1

Assigned to Control

23

Assigned to Treatment

\section{3}

Wave 2

Assigned to Control

Assigned to Treatment

Wave 3

Assigned to Control

Assigned to Treatment

Panel B. Number of people still in the sample at the time the Logbooks were introduced

\begin{tabular}{|c|c|c|c|c|}
\hline TOTAL & 200 & 74 & 27 & 301 \\
\hline Control & 111 & 34 & 17 & 162 \\
\hline Treatment & 89 & 40 & 10 & 139 \\
\hline Wave 1 & 32 & 43 & 0 & 75 \\
\hline Control & 16 & 18 & & 34 \\
\hline Treatment & 16 & 25 & & 41 \\
\hline Wave 2 & 65 & 31 & 22 & 118 \\
\hline Control & 33 & 16 & 12 & 61 \\
\hline Treatment & 32 & 15 & 10 & 57 \\
\hline Wave 3 & 103 & 0 & 5 & 108 \\
\hline Control & 62 & & 5 & 67 \\
\hline Treatment & 41 & & 0 & 41 \\
\hline
\end{tabular}

\section{Panel C. Study Sample: Total number of people that completed Logbooks}

\begin{tabular}{|c|c|c|c|c|}
\hline TOTAL & 170 & 55 & 25 & 250 \\
\hline Control & 96 & 24 & 15 & 135 \\
\hline Treatment & 74 & 31 & 10 & 115 \\
\hline Wave 1 & 26 & 35 & 0 & 61 \\
\hline Control & 16 & 14 & & 30 \\
\hline Treatment & 10 & 21 & & 31 \\
\hline Wave 2 & 54 & 20 & 21 & 95 \\
\hline Control & 30 & 10 & 11 & 51 \\
\hline Treatment & 24 & 10 & 10 & 44 \\
\hline Wave 3 & 90 & 0 & 4 & 94 \\
\hline Control & 50 & & 4 & 54 \\
\hline Treatment & 40 & & 0 & 40 \\
\hline
\end{tabular}

Panel D. Compliance with Treatment among those assigned to Treatment Group

Total that could not be traced for account offer

Total offered account

Total that refused account offer

Total that opened account

\begin{tabular}{cccc}
26 & 8 & 5 & 39 \\
104 & 40 & 12 & 156 \\
15 & 4 & 2 & 21 \\
89 & 36 & 10 & 135 \\
\hline
\end{tabular}

Notes: Attrition from the sample between the baseline and the introduction of the logbook (the drop from Panel A to Panel B) was due to relocation of respondents outside of the study area. This type of attrition was higher for wave 3 and wave 1 than wave 2, because the gap between baseline and the rollout of the logbook was much longer (14 Banths on average for wave 3 and 9 months for wave 1) compared to wave 2 (5 months). Attrition in the Logbook sample (the drops from Panel B to Panel C) was due to refusals. 


\begin{tabular}{|c|c|c|c|c|}
\hline & (1) & $(2)$ & (3) & (4) \\
\hline & $\begin{array}{l}\text { Our Study } \\
\text { Sample }\end{array}$ & $\begin{array}{c}\text { Western Kenya: } \\
\text { Census of unbanked } \\
\text { households in } 3 \\
\text { villages }\end{array}$ & $\begin{array}{c}\text { Central Uganda: } \\
\text { Unbanked Households in } \\
19 \text { Parishes }\end{array}$ & $\begin{array}{c}\text { Southern Malawi: } \\
\text { Unbanked Households in } \\
72 \text { villages }\end{array}$ \\
\hline & $2006-2008$ & Fall $2009^{a}$ & Fall $2010^{\mathrm{b}}$ & Spring $2011^{\mathrm{b}}$ \\
\hline \multicolumn{5}{|l|}{ Demographics } \\
\hline Age & $\begin{array}{c}33.71 \\
(10.48)\end{array}$ & $\begin{array}{c}40.15 \\
(16.72)\end{array}$ & $\begin{array}{l}36.29 \\
(12.00)\end{array}$ & $\begin{array}{c}39.55 \\
(19.07)\end{array}$ \\
\hline Married & 0.71 & 0.70 & 0.71 & 0.73 \\
\hline Number of Children & $\begin{array}{c}3.31 \\
(2.23)\end{array}$ & $\begin{array}{c}3.35 \\
(2.34)\end{array}$ & $\begin{array}{l}5.05 \\
(3.04)\end{array}$ & $\begin{array}{c}2.67 \\
(1.74)\end{array}$ \\
\hline Education & $\begin{array}{c}6.34 \\
(3.19)\end{array}$ & $\begin{array}{c}5.95 \\
(3.38)\end{array}$ & $\begin{array}{l}5.50 \\
(2.97)\end{array}$ & $\begin{array}{c}5.60 \\
(2.91)\end{array}$ \\
\hline Literate & 0.74 & 0.51 & 0.76 & 0.61 \\
\hline Participates in ROSCA & 0.74 & 0.40 & 0.23 & 0.06 \\
\hline ROSCA Contributions in Last Year (in USD) & $\begin{array}{c}53.83 \\
(72.88)\end{array}$ & $\begin{array}{c}60.07 \\
(102.22)\end{array}$ & $\begin{array}{c}36.65 \\
(58.36)\end{array}$ & $\begin{array}{c}33.15 \\
(49.48)\end{array}$ \\
\hline Value of Animals Owned (in USD) & $\begin{array}{c}69.01 \\
(132.62)\end{array}$ & $\begin{array}{c}69.99 \\
(171.45)\end{array}$ & $\begin{array}{c}122.88 \\
(612.20)\end{array}$ & $\begin{array}{c}61.52 \\
(120.35)\end{array}$ \\
\hline Value of Durable Goods Owned (in USD) & $\begin{array}{c}71.13 \\
(152.96)\end{array}$ & $\begin{array}{l}126.30 \\
(131.36)\end{array}$ & $\begin{array}{c}269.57 \\
(1054.84)\end{array}$ & $\begin{array}{c}123.48 \\
(362.68)\end{array}$ \\
\hline Received Loan from Bank in Past Year ${ }^{c}$ & 0.04 & 0.05 & 0.06 & 0.06 \\
\hline \multicolumn{5}{|l|}{ Risk Preferences } \\
\hline Percent invested in Risky Asset ${ }^{\mathrm{d}}$ & 0.64 & 0.59 & 0.63 & 0.72 \\
\hline \multicolumn{5}{|l|}{ Cognitive Skills } \\
\hline Raven's matrix score (percent correct) & 0.49 & - & - & 0.44 \\
\hline Observations & 250 & 2390 & 2160 & 2252 \\
\hline
\end{tabular}




\section{Appendix: Robustness Checks}

\section{Excluding those who might have anticipated receiving a loan}

Like many microfinance institutions, the village bank we worked with offers both savings and credit products. Once people have an account with the bank, they can become eligible for a loan. To qualify for a loan, an individual must first purchase a share in the bank. Three months after purchasing a share, an individual is eligible to apply for a loan (the maximum amount is a multiple of the amount of share capital owned). Clearly, if many treatment individuals had gotten loans during the study period, this would likely bias our estimated impacts of expanding access to savings alone. Since only a small number of individuals in our sample actually got loans (only $1.6 \%$ of respondents got loans within a year), this is not a major concern.

That said, it remains theoretically possible that some individuals in our treatment group expected such loans in the future, and were able to borrow working capital from friends and relatives in the short run, in anticipation of a bank loan (and presumably, higher future profits) later. This is probably very unlikely in this case, since it is difficult for people to access credit informally even if they have physical assets as collateral, and possible future access to credit was not at all guaranteed by getting access to an account. Nevertheless, we formally explore the impact of these individuals on our estimated impacts in Appendix Table A3. In this Table, we replicate the analysis presented in Tables 3 and 4, after excluding from the sample those who received a loan from the bank within a year after account opening (note that this is overly strong, since the logbooks were collected 4-6 months after opening). This reduces the sample size and increases the size of the standard errors, but all the coefficients have the same magnitude and sign as they do in Tables 3 and 4, suggesting that the effects observed on investment and expenditures are not driven by loans or the anticipation of loans.

\section{Size of Deposits}

As can be inferred from Figure 1, even those individuals who actively used the account did not make many transactions. For instance, the median number of deposits made in the first 6 months among respondents who actively used the account was just 4.6. This means that the average deposit size was large: the median among active women was about $300 \mathrm{Ksh}$ (US $\$ 4.30)$, which is equivalent to about 1.6 days of mean expenditures for women in the sample. For some women, the average deposit size was much larger than this.

By definition, those who make very large deposits must be able to save up at home, and therefore should not particularly benefit from the accounts. To check this, we run our main 
regressions while excluding those whose average deposit size was larger than the median deposit in the sample. The results are presented in Appendix Table A4. Although removing half of the treatment group considerably reduces statistical power, we obtain coefficients on the treatment effects of similar magnitude in this specification as in Tables 3 and 4. 
Table A3. Excluding Those Individuals that Were Planning for a Loan (1) (2)

(2) (3)

(4)

(5)

(6)

(7)

(8)

(9)

Amount invested in Business Total Expenditures $\quad$ Food Expenditures Private Expenditures

Trimming

Panel A. Intention-to-Treat Estimates (ITT)

Sampled for Savings Account

$\begin{array}{ccc}\text { None } & \text { None } & \text { Top 5\% } \\ & & \\ 188.19 & 219.53 & 86.50 \\ (106.09)^{*} & (150.66) & (62.54) \\ & -128.51 & -25.56 \\ & (229.88) & (86.20) \\ 240 & 240 & 240\end{array}$

None

None

None

None

None

None

Sampled for Savings Account* Boda

20.30

24.82

9.45

12.50

8.33

6.58

Observations

240

$(18.74)$

$(6.14)$

(43.11)

-5.43
$(14.74)$

$0.077^{*}$

246

246

246

246

7.25

$p$-value for overall effect $=0$

$p$-value for effect for women $=0$

$\begin{array}{ll}0.146 & 0.168 \\ 0.567 & 0.337\end{array}$

0.191

0.187

0.125

0.517

0.115

$0.026^{* *}$

$p$-value for effect for bodas $=0$

0.337

0.570

$0.093 *$

0.207

Panel B. Mean and Std. Dev. of Dependent Variable in Control Group

Female Vendors: Mean

$\begin{array}{ccc}352.01 & 240.84 & 167.13 \\ (460.03) & (224.20) & (115.77) \\ 11.30 & 11.30 & 131.21 \\ (8.81) & (8.81) & (106.84) \\ \end{array}$

84.42

(48.19)

59.24

(31.43)

21.22

(23.66)

Bodas: $\quad \begin{aligned} & \text { Mean } \\ & \text { Std. Dev }\end{aligned}$

(106.84)

25.12
$(23.77)$

Notes: See Table 2 notes. 


$\begin{array}{llllllll}(1) & (2) & (3) & (4) & (5) & (6) & (7) & (8)\end{array}$

Amount invested in Business Total Expenditures $\quad$ Food Expenditures Private Expenditures

Trimming

Panel A. Intention-to-Treat Estimates (ITT)

Sampled for Savings Account

None
161.17
$(133.64)$

Sampled for Savings Account* Boda

Observations

$p$-value for overall effect $=0$

$p$-value for effect for women $=0$

$p$-value for effect for bodas $=0$

211

None Top 5\%

None

None

None

$\begin{array}{lll}249.18 & 91.77 \quad 28.19\end{array}$

28.19
$(17.33)$

34.37

(21.40)

$\begin{array}{ll}(207.54) & (77.90) \\ -306.72 & -93.71\end{array}$

-93.71
$(75.11)$

$211 \quad 211$

0.229

$\begin{array}{ll}0.231 & 0.240 \\ 0.398 & 0.921\end{array}$

217

7.63
$(48.23)$

11.26
$(6.44)^{*}$

None

None

None

Panel B. Mean and Std. Dev. of Dependent Variable in Control Group

Female Vendors: Mean

363.84

$(471.69)$

11.30

(8.81)

0.105

217

$(8.47)^{*}$

10.5

$(4.48)^{* *}$

9.12
$(4.71)^{*}$

1.47
$(16.38)$

9.56
$(13.19)$

217

217

217

217

Bodas:

Std. Dev.

Std. Dev.

Notes: See Table 2 notes.

\begin{tabular}{cc}
239.80 & 169.14 \\
$(222.03)$ & $(117.77)$ \\
11.30 & 131.21 \\
$(8.81)$ & $(106.84)$ \\
\hline
\end{tabular}

0.110

0.082*

$0.098^{*}$

$0.019^{* *}$

0.254

0.054*

0.132

$\begin{array}{cc}86.96 & 21.08 \\ (54.96) & (23.44) \\ 59.24 & 25.12 \\ (31.43) & (23.77)\end{array}$

